\title{
Establishing the context for your research project
}

\author{
Janet Clapton
}

\section{Introduction}

The purpose of this article is to describe a process and resources which will enable a researcher to contextualise a new research project within its field. Library and Information Science (LIS) professionals will find this process useful not only for their own practitioner research, but also, with appropriate adaption to different subject areas, for finding information at work for their customers or clients.

My own work role is information specialist support for research commissioning in the social care field; from this I have drawn general tips for background scoping in a social science field such as library and information science. Variety of sources is key: the sources drawn on here include bibliographic databases, research databases, portals, key organisations' websites, discussion groups, conferences and awards. This list is not intended to be exhaustive, and can only provide a snapshot of a changing environment, but these resources can act as a starting point for further detailed preparation. To supplement this article, the Library and Information Research (LIRG) website links list has been expanded and updated: please see www.cilip.org.uk/specialinterestgroups/bysubject/research/links.

\section{Approach}

The term 'scoping' does not have a commonly accepted definition (Arksey et al., 2005, and Davis et al., 2009). Here, background scoping means establishing what activities are going on in a particular field (including policy, practice and current research), who the relevant organisations and individuals are, and what has already been published on the topic. Grayson and Gomersall (2003) neatly describe problems specific to searching in the social sciences, including: the diversity of literature, sources and database features, and the lack of single controlled language tool for searching. They recommend a broad approach, combined with strong awareness of the range of sources available and how to use them.

\section{Janet Clapton}

Janet Clapton is Project Information Manager at the Social Care Institute for Excellence.

Email: janet.clapton@scie.org.uk 
For more details on how establishing the research context fits into the process of compiling a research proposal, see Juliet Eve's recent article in Library and Information Research (Eve, 2008).

In my research support role, I manage and standardise the scoping process by using a checklist and templates. Useful documents include:

- Spreadsheet - showing search sources, search terms and outputs - primarily intended as a device for tracking progress, this could later form the foundation of a more detailed search strategy for a literature review.

- Database of bibliographic references, ideally built using reference management software such as EndNote or Reference Manager. Such software usually contains tools for inserting and ordering citations and bibliographies in later research reports.

- Mindmap of weblinks: mindmapping is a method of gathering and presenting ideas (see www.buzanworld.com/Home1.htm) and is a useful format for presenting further information such as weblinks. The mindmap template is organised into categories such as policy, government agencies, academic institutions, experts, professional bodies, third sector bodies, service user groups, discussion groups and media sources. There is an example of a mindmap in the supplementary file associated with this article.

Freemind is an example of free software for mindmapping (http://freemind.sourceforge.net/wiki/index.php/Main_Page) but commercial products such as MindGenius are also available.

- Summary report describing the overall findings. Template headings include:

○ Brief

○ Short summary of findings

- Description of types of output

- Sources drawn on

- Challenges encountered on this topic

○ How much time was spent

○ Potential for further work

- Key documents, authors and organisations

The output is a bibliography derived from a balanced but exploratory literature search, a collection of weblinks in a mindmap or list, and the summary report.

\section{Sources}

It is a good idea to use a variety of approaches when gathering information. Traditional keyword searching is a good starting point, but authors such as Sandieson (2006) promote other methods such as 'pearl harvesting' or drawing on relevant items to give clues for finding more. Ramer (2005) recommends a similar process for relevant websites: 'site-ation'. 
Given the bias that is introduced by such factors as time lag between research study and publication, lack of reporting of negative results in peer reviewed journals, and the challenge of finding grey literature (often a key type of source in a practitioner-led field), it is sensible to draw on as wide a range of sources as possible.

\subsection{Bibliographic databases}

Like social care, the LIS field is covered in several different disciplines, so when considering bibliographic databases, select representative databases from the following range:

- LIS specific sources, e.g. Library and Information Service Abstracts, Information Research Watch International (both available to CILIP members via 'Member resources' on the CILIP website: www.cilip.org.uk)

- Sector specific resources, such as law, engineering or health, e.g. PubMed www.ncbi.nlm.nih.gov/pubmed/

- Education, e.g. Education Resources Information Center (ERIC) www.eric.ed.gov/

- Computer science, e.g. CiteSeerX http://citeseerx.ist.psu.edu/

- Business and management, e.g. Business Source Premier (subscription required)

- Broad social science sources, e.g. International Bibliography of the Social Sciences (subscription required)

- Multi-discipline databases, e.g. British Library catalogue http://catalogue.bl.uk

\subsection{Access}

Unless you are linked to an academic institution, you will probably be looking for free access to bibliographic databases. Luckily, CILIP membership (and access to the CILIP website) opens up possibilities (see 'Member resources' section of www.cilip.org.uk).

If you can get to the British Library reading rooms at St Pancras, a similar range of subscription databases are freely available to you without restriction (see www.bl.uk/eresources/main.shtml ). You will need to register in advance for a Reader Pass but this can be obtained on the basis of CILIP membership. For remote resources, the 'Help for Researchers' web page (www.bl.uk/reshelp/index.html) links through to a Librarianship and Information Science page. 


\subsection{Coverage}

Aspects to consider include: size of database; years of coverage; alteration to selection criteria over time; past mergers with other databases; geographical coverage (which may be nominal for some regions); and languages. However, in the first instance it is likely that you will not have time to familiarise yourself with all aspects of coverage and will only be able to gain an impression.

\subsection{Search functions}

General considerations include whether there is a thesaurus and how useful it is; availability and reliability of limiters; quality of indexing; whether abstracts are available; download features; utilities which don't work as you expect; and results presentation.

\subsection{Research project databases}

Research project databases complement searches for published research by helping you answer the question: "What's going on?" Or rather, "what went on?" Unfortunately, initial entries are often not updated when a project is complete and it can be difficult to track down subsequent publications, as they may not have the same title or author order.

Useful examples include:

- E-prints in Library and Information Science http://eprints.rclis.org/information.html

- Information Research Watch International (available via CILIP Member resources) www.cilip.org.uk/publications/irwi

- Library and Information Research Directory of Current Research in LIS departments in UK and Ireland www.cilip.org.uk/specialinterestgroups/bysubject/research/publications

Repositories can also fulfill a similar function, see:

- British Library Research Archive http://sherpa.bl.uk/

- OpenDOAR www.opendoar.org/

\subsection{Journals}

In theory, journal content appears in bibliographic databases. However, the effort required to establish which journals are covered on which database, the time lag for content to be indexed onto the database, selection criteria and lack of access to author abstracts all mean that journal searching complements bibliographic database searching. In recent years, table of contents searches have made it relatively simple to search across a journal title or even across aggregated titles. However, simple is generally what these searches are: often a single phrase, returning somewhat unexpected results. Hand-searching gets around the problem of poor search utilities, but has a very high effort / benefit ratio. 
Relevant journals include:

- 13 Emerald LIS journals listed as available to CILIP members at www.cilip.org.uk/publications/emerald

- 4 Sage LIS journals listed as available to CILIP members at www.cilip.org.uk/publications/researchjournals

- Health Information and Libraries Journal www.wiley.com/bw/journal.asp?ref=1471-1834

Numerous journals are available on Open Access:

- Evidence Based Library and Information Practice http://ejournals.library.ualberta.ca/index.php/EBLIP

- Information Research http://informationr.net/ir/index.html

- Library and Information Research www.cilipjournals.org.uk/lir

- Library and Information Science Research Electronic Journal http://libres.curtin.edu.au/

- LIBRI: International Journal of Libraries and Information Services www.librijournal.org/

\subsection{Newsletters}

Whilst not peer reviewed, the strength of newsletters lies in their reporting of practice and current awareness about issues and organizations. Examples include:

- Ariadne www.ariadne.ac.uk/

- Free Pint www.freepint.com/ which also acts as a portal and community

- Sconul Focus www.sconul.ac.uk/publications/newsletter/

\subsection{Portals and resource lists}

Portals and resource lists consist of pre-screened material, usually where an information professional has done some of the leg work for you - a valuable backup to search results. Selection criteria are rarely stated, but the concentrated nature of such resources generally means they are not too time consuming to browse or search. A structured index is usually available. Examples of this type of resource include:

- BUBL link: Library and Information Science Research http://bubl.ac.uk/link/l/libraryandinformationscienceresearch.htm

- Phil Bradley's web page www.philb.com/

- CILIP www.cilip.org.uk

- Communication Institute for Online Scholarship www.cios.org/www/tocs/tablesnew.htm

- Economic and Social Research Council www.esrc.ac.uk/ESRCInfoCentre/index.aspx 
- Intute www.intute.ac.uk - the relevant section seems to be Museums / Libraries / Archives, also Research tools and methods www.intute.ac.uk/socialsciences/researchtools/

- LibEcon (European Library Statistics database, newsletters, reports) www.libecon.org/default.asp

- Library statistics www.cilip.org.uk/informationadvice/standardsandstats/statistics

- LISU (previously the Library and Information Statistics Unit) www.lboro.ac.uk/departments/dils/lisu/index.html

- The Researching Librarian www.researchinglibrarian.com/

- Scirus www.scirus.com/

\subsection{Discussion lists}

Discussion list content can be searched for relevant topics, or a post can be used to ask practice research questions of list readers. JISCmail (www.jiscmail.ac.uk) contains more than 100 LIS lists e.g. LIS-LIRG, LIS-LINK.

Communities can be tapped into in a similar way, e.g. CILIP Communities (http://communities.cilip.org.uk/)

Wider Web 2.0 resource use, although important, is outside the scope of this article.

\subsection{Conferences}

Conferences are a great source of information about current research, but time and budgets to attend them are limited, and conference proceedings can be quite challenging to get hold of. Write-ups in trade magazines are useful, and eventually the individual presentations may appear online.

Conference papers and presentations are increasingly turning up in institutional repositories (e.g. University of Southampton (http://eprints.soton.ac.uk) and in online presentation sharing sites such as Slideshare (www.slideshare.net). Some subscription databases offer search facilities for conference papers, e.g. Zetoc (http://zetoc.mimas.ac.uk/) and Web of Knowledge (http://isiwebofknowledge.com/).

To find out about impending conferences, try the CILIP events listing at www.cilip.org.uk/training/calendar or wait for postings to arrive from JISCmail discussion lists. Another resource is Information Science Conferences Worldwide (www.conferencealerts.com/library.htm).

Significant international events include:

- IFLA www.ifla.org/en/annual-conference

- Internet Librarian www.internet-librarian.com/2009/

- Online Information www.online-information.co.uk/index.html

- Umbrella www.umbrella2009.org.uk/ 
Sometimes connected with conferences, award-winning projects can also be useful sources of (especially) practitioner research. Discussion lists are again probably the most useful way to keep up to date on award news.

\subsection{Organisations}

There are very many potentially relevant organisations; a mindmap can help organise and reorganise them by category. Examples of organisations include:

- Association of Librarians and Information Professionals in the Social Sciences (ALISS) www.alissnet.org.uk/

- British Association for Information \& Library Education and Research (BAILER) www.bailer.org.uk ${ }^{1}$

- British Computer Society Information Retrieval Specialist Group http://irsg.bcs.org/

- CILIP: the Chartered Institute of Library and Information Professionals www.cilip.org.uk. LIRG is a Special Interest Group of CILIP.

- Commercial, Legal and Scientific Information Group (CLSIG) www.cilip.org.uk/specialinterestgroups/bysubject/clsig/default.htm

- Evidence Network https://www.kcl.ac.uk/schools/sspp/interdisciplinary/evidence/

- International Association of Technological University Libraries (IATUL) www.iatul.org/

- International Federation of Library Associations and Institutions (IFLA) www.ifla.org

Divisions include:

- Division of Education and Research www.ifla.org/en/education-and-research

Sections include:

- Library Theory and Research Section www.ifla.org/en/library-theory-and-research

- Statistics and Evaluation Section www.ifla.org/en/statistics-and-evaluation

- Museums, Libraries and Archives Council (MLA) www.mla.gov.uk/, see also its Research section: www.mla.gov.uk/what/research

- Research Information Network www.rin.ac.uk/

- SOROS Foundations Network - See 'Information Program' www.soros.org/initiatives/information

- UkeIG: The UK e-Information Group www.ukeig.org.uk/

\footnotetext{
${ }^{1}$ At the time of publication this site was under construction
} 
- UKOLN www.ukoln.ac.uk/

\section{Procedure: further suggestions}

Be creative when developing search sources and terms - you will definitely be learning as you go along. Iteration is the norm rather than the exception. Filters, if available, should be used sparingly and critically - for scoping, you are likely to get better results by scanning a broad search output.

Mind the gaps - maintain a highly critical approach to the result of your searching and context-gathering. In light of lack of controlled language tools, this is likely to include the question, "Is my search term retrieving what I thought it would?" This applies even more to website searches than to bibliographic databases.

What's going on elsewhere? My own unpublished investigations of 60 mental health-relevant organisations' websites showed that very few organisations publish their current research programme or future plans. A good back up is to speak to knowledgeable contacts: speak to an expert at a conference, or contact information staff at a relevant organisation. A ten minute conversation with a knowledgeable colleague could save you hours of work.

All information and sources become out of date, and the research literature field continues to evolve, so during your current awareness it is wise to keep an eye out for new sources and terms as well as new research. In the social care field, I estimate the shelf life of background scoping to be around 6 months - this time scale could be relevant if you, say, take a year out from your $\mathrm{PhD}$.

\section{Conclusion}

This article outlines an approach and a range of resources for establishing the context for your research or that of your service users. It is not exhaustive, but provides a framework for managing the process, and suggested resources.

Further contributions are welcomed to the resources section of the LIRG website www.cilip.org.uk/specialinterestgroups/bysubject/research/links and to the Library and Information Research Directory www.cilip.org.uk/specialinterestgroups/bysubject/research/publications - please follow the prompts on both sites to suggest resources or add your research. 


\section{References}

Arksey, H. and O'Malley, L. (2005) Scoping studies: towards a methodological framework. International Journal of Social Research Methdology, 8(1), 19-32. Also available from http://eprints.whiterose.ac.uk/1618/ [accessed 15.8.09].

Davis, K., Drey, N. and Gould, D. (In press) What are scoping studies? A review of the nursing literature. International Journal of Nursing Studies.

Eve, J. (2008). Writing a research proposal: planning and communicating your research ideas effectively. Library and Information Research [online], 32(102), 18-28. URL: http://www.lirg.org.uk/lir/ojs/index.php/lir/article/view/92/136 [accessed 15.8.09].

Grayson, L. and Gomersall, A. (2003) A difficult business: Finding the evidence for social science reviews. ESRC UK Centre for Evidence Based Policy and Practice, Working Paper 19. London: ESRC UK Centre for Evidence Based Policy and Practice. URL:

http://kcl.ac.uk/schools/sspp/interdisciplinary/evidence/publications/wp19.html [accessed 15.8.09].

Ramer, S. (2005). Site-ation pearl growing: methods and librarianship history and theory. Journal of the Medical Library Association, 93(3), 397-400. URL: www.pubmedcentral.nih.gov/articlerender.fcgi?artid=1175807 [accessed 15.8.09].

Sandieson, R. (2006). Pathfinding in the research forest: The pearl harvesting method for effective information retrieval. Education and Training in Developmental Disabilities, 41(4), 401-409. URL:

http://publish.edu.uwo.ca/robert.sandieson/downloads/ETDD.pdf [accessed 17.8.09].

Note: weblinks to relevant resources are provided in the text. 